\title{
Tamoksifen Tedavisi Altında Yeni Tanı Diyabet Gelişimi
}

\author{
${ }^{1}$ Pinar Yildiz \\ ${ }^{1}$ Eskişehir Osmangazi Üniversitesi Tıp Fakültesi İç Hastalıkları ABD. \\ e-posta: pinaresogu@gmail.com
}

ÖZET: Diyabet ve kanser arasındaki ilişki bilinmektedir. Diyabeti olan hastalarda postmenopozal meme kanseri sıklığı artmıştır. Ayrıca meme kanserli kadınlar diyabet gelişimi açısından da risk altındadır. Bunun yanında son dönemde meme kanseri tedavisinde kullanılan tamoksifenin de diyabet gelişiminde rol oynayabildiği bildirilmiştir. Tamoksifen, primer meme kanserinin adjuvan hormonal tedavisinde yaygın olarak kullanılmakta olan bir nonsteroidal östrojen antagonistidir. Pankreatik beta hücreleri üzerinde insülin inhibisyonu oluşturarak insülin direnci gelişimine yol açar. Bu gözlemsel çalısmada amacımız hastanemiz onkoloji polikliniğinde takipli meme kanseri olgularının tamoksifen tedavisi öncesi ve sonrasında diyabet gelişimi açısından retrospektif analizinin yapılması ve bununla birlikte tedavi takibinin yeniden gözden geçirilmesidir. Gereç ve Yöntem: Hastanemiz Onkoloji polikliniğinde meme kanseri tanısıyla takip edilen ve tedavisinde tamoksifen kullanılan hastaların retrospektif dosyaları incelendi. Bilgiler sadece dosya kayıtları esas alınarak değerlendirildi. Tamoksifen başlanmadan önceki ve son başvuru açlık glukoz değerleri değerlendirildi. Yeni tanı konulan diyabet hastaları kaydedildi. Hastaların meme kanseri tanısı aldıklarında menopoz durumları, özgeçmiş ve soygeçmiş bilgilerinin kaydı yapıldı. Özgeçmişinde diyabet tanısı olanlar çalışmaya alınmadı. Çalışmamıza 44 meme kanseri olgusu dahil edildi, 30 kişi tamoksifen tedavisi almış hasta grubu, 14 kişi tamoksifen tedavisi almayan kontrol grubu olarak

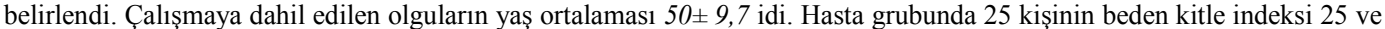
üstündeydi. Tamoksifen kullananlarda ortalama kullanım süresi $1.88 \pm 1,68$ idi. Çalışmaya aldığımız hasta grubunda 15 kişide tamoksifen tedavisi sonrasında yeni tanı diyabet gözlemlendi. Tüm çalışma grubunda tanı aşamasında ve en son kontroldeki kan glukoz değerleri değişimi arasında istatistiksel anlamlı fark mevcuttu $(p=0.001)$. Hastaların kontrol grubuna göre en son kontrol glukoz ölçüm değerleri kontrol grubuna göre istatistiksel anlamlı yüksekti $(t=5.661, p<0.001)$. Tartışma ve Sonuç Diyabetin kanser gelişimindeki rolü tanımlanmış ve bu ilişki bașta hiperinsülinizm olmak üzere, insülin direnci, obezite, beslenme alışkanlıkları, IGF-1 yüksekliği gibi farklı mekanizmalarla açıklanmaya çalışılmıştır. Hayvan çalıșmalarında tamoksifenin beta hücre apopitozunu arttırdığı ve insülin sekresyonunu azalttığı gösterilmiștir. Bu sayede diyabete yatkınlık yarattı̆̆ı açıklanmaktadır. Çalışmamızda tamoksifen tedavisi altındaki 30 kişsinin 15 'inde yeni tanı diyabet gelişmiştir. Tamoksifenin östrojen reseptörü pozitif hastalara başlanması ve bu hastaların östrojen reseptörü negatif olanlara göre östrojen maruziyetinin ve dolayısıyla diyabete yatkınlığının da fazla olmasının, diyabet gelişiminde rol oynadığı savunulmuştur. Çalışmamızda plazma glukoz değerleri açısından değerlendirildiğinde hastaların son kontrollerindeki ölçümlerin tamoksifen kullananlarda kullanmayanlara göre istatistiksel anlamlı olarak daha yüksek bulunmuştur. Sonuç olarak çalışmamız tamoksifenin insülin direnci ve diyabet gelişimi açısından etkilerini değerlendirmede prospektif randomize kontrollü geniş ölçekli çalışmalara ihtiyaç duyulduğunu göstermiştir. Tamoksifen tedavisi öncesinde hastaların metabolik profillerinin belirlenmesinin yan etki gelişimi açısından ön gördürücü olacağ 1 düşüncesindeyiz.

ANAHTAR KELIMELER: Diyabet, meme kanseri, tamoksifen

ABSTRACT: It is known the relationship between diabetes and cancer. The diabetic patient has a higher risk for postmenopausal breast cancer. In addition, women with breast cancer are at risk for developing diabetes. Besides recently used tamoxifen in the treatment of breast cancer plays a role in the development of diabetes have been reported. Tamoxifen is non-steroidal estrogen antagonist that is commonly used in adjuvant hormonal therapy of primary breast cancer. The aim of this observational study of oncology outpatient clinic of our hospital in the follow-up of patients with breast cancer before and after tamoxifen therapy retrospective analysis done in terms of the development of diabetes and treatment follow-up, however, is reconsidered. Materials and Methods Oncology clinic of our hospital with a diagnosis of breast cancer and tamoxifen used in the treatment of patient files were analyzed retrospectively. Information was evaluated only on the basis of the records. Tamoxifen started fasting glucose values were assessed before and deadlines. Patients with newly diagnosed diabetes were recorded. When patients are diagnosed with breast cancer in menopausal status, personal and family information was recorded. In his history of diagnosed diabetes were excluded from the study. In our study, 44 cases of breast cancer were enrolled, 30 patients who received tamoxifen therapy group people, 14 people in the control group who did not receive tamoxifen therapy was determined. The mean age of the patients included in the study was $50 \pm$ 9.7. The mean year of tamoxifen used is $1,88 \pm 1,66$. The mean that we studied in patients after tamoxifen therapy 15 people with newly diagnosed diabetes was observed. In the entire study group at diagnosis and the latest changes in the control of blood glucose values did not differ statistically significant $(p=0.001)$ Using tamoxifen group compared to the control group, the most recent glucose measurements were statistically significantly higher $(t=5.661, p<0.001)$. Discussion and Conclusion Defined role of diabetes in the development of cancer, and this association, including particularly hyperinsulinism, insulin resistance, obesity, eating habits, IGF-1 has been explained by different mechanisms. Tamoxifen in animal studies to increase beta-cell apoptosis and has been shown to reduce insulin secretion. In this way, susceptibility to diabetes are disclosed to create. In our study, 30 people under tamoxifen therapy in 15 newly diagnosed diabetes has developed. To start tamoxifen for estrogen receptor-positive patients, and these patients compared to those with estrogen receptor negative estrogen exposure and therefore also be more prone to diabetes, diabetes has been argued to play a role in the development. On the basis of our study, plasma glucose values measured in the last evaluation, compared with those in the tamoxifen users were statistically significantly higher. In conclusion, our study of tamoxifen for the development of insulin resistance and diabetes, to evaluate the impact of large-scale prospective randomized controlled studies are needed to show that. Tamoxifen metabolic profile of patients prior to treatment to determine the predictors for the development of side effects would believe. 


\section{Giriş}

Diyabet ve kanser arasındaki ilişki bilinmektedir. Diyabeti olan hastalarda postmenopozal meme kanseri sıklığ $\operatorname{artm}_{1} \operatorname{şı}^{1-5}$. Bu durum hiperinsülinizm, insülin direnci, obezite ve kanser arasındaki ilişki ile açıklanmaya çalışılmıştır ${ }^{6}$. Beraberinde meme kanseri olan kadınların diyabet gelişimi açısından da risk altında olduğu bildirilmiştir ${ }^{2}$. Bunun yanında son dönemde meme kanseri tedavisinde kullanılan tamoksifenin de diyabet gelişiminde rol oynayabildiği bildirilmiştir. Tamoksifen, primer meme kanserinin adjuvan hormonal tedavisinde yaygın olarak kullanılmakta olan bir nonsteroidal östrojen antagonistidir. Meme dokusu üzerine antiöstrojenik etki gösterirken, serum lipitleri, kemik ve endometrium üzerine belirgin östrojenik etki göstermekte ve buna bağlı olarak tamoksifen kullanan hastalarda endometrial patoloji gelişme riski artmaktadır. Tamoksifen ile ilgili hafif bulantı, deri döküntüsü, sıcak basması, ödem ve kilo artışı gibi yan etkiler sık görülenlerdendir. Bunun yanında hipertrigliseridemi, tromboemboli ve retinit gibi nadir ama ciddi yan etkileri bilinmektedir $^{7,8}$.Tamoksifen östrojen inhibisyonuna ve bununla birlikte pankreatik beta hücreleri üzerinde insülin inhibisyonu ve insülin direnci gelişimine yol açar ${ }^{9-13}$. Hayvan çalışmalarında tamoksifenin direkt olarak insulin supresyonu yaptığı gösterilmiştir ${ }^{14}$. Bu gözlemsel çalışmada amacımız hastanemiz onkoloji polikliniğinde takipli meme kanseri olgularının tamoksifen tedavisi öncesi ve sonrasında diyabet gelişimi açısından retrospektif analizinin yapılması ve bununla birlikte tedavi öncesinde ve takipte dikkat edilmesi gereken profilin yeniden gözden geçirilmesidir.

\section{Gereç ve Yöntem}

Hastanemiz Onkoloji polikliniğinde meme kanseri tanısıyla takip edilen ve tedavisinde tamoksifen kullanılan ve kullanılmayan 64 hastanın retrospektif dosyaları incelendi. Bilgiler sadece dosya kayıtları esas alınarak değerlendirildi. Dosyaları tam olarak değerlendirilen 44 hasta çalışmaya alındı. Tamoksifen başlanmadan önceki ve son başvuru açlik glukoz değerleri değerlendirildi. Yeni tanı konulan diyabet hastaları kaydedildi. Hastaların meme kanseri tanıs1 aldıklarında menopoz durumları, özgeçmiş ve soygeçmiş bilgilerinin kayd 1 yapıldı. Özgeçmişinde diyabet tanısı olanlar çalışmaya alınmadı.

\section{İstatistiksel Analiz}

$\mathrm{Bu}$ çalışmada sürekli normal dağılım gösteren değişkenler için $\mathrm{t}$ testi ile analiz edildi. İstatistiksel önemlilik için $p<0.05$ değeri kabul edildi. İstatistiksel analizler için IBM SPSS Statistics 20.0 (SPSS Inc., Chicago, Illinois) programı kullanıldı.

\section{Bulgular}

Çalışmamıza 44 meme kanseri olgusu dahil edildi, 30 kişi tamoksifen tedavisi almış hasta grubu, 14 kişi tamoksifen tedavisi almayan kontrol grubu olarak belirlendi. Çalışmaya dahil edilen olguların yaş ortalaması $50 \pm 9,7$ idi. Hasta grubunda 25 kişinin, beden kitle indeksi (BKI) 25 ve üstündeydi. Çalışma grubumuzda tamoksifen kullanan ve kullanmayan hastalarda steatoz açısından istatistiksel anlamlı fark saptanmadı $(p=0,226)$. Çalışmaya aldığımız hasta grubunda 15 kişide tamoksifen tedavisi sonrasında yeni tanı diyabet gözlemlendi. Kontrol grubunda ise 5 hastada yeni tan DM gözlendi, aralarında istatistiksel anlamlı fark saptanmadı $(p=0,375)$. Tüm çalışma grubunda tanı aşamasında ve en son kontroldeki kan glukoz değerleri değişimi arasında istatistiksel anlamlı fark mevcuttu $(p=0.001)$. Hastaların kontrol 
grubuna göre en son kontrol glukoz ölçüm değerleri kontrol grubuna göre istatistiksel anlamlı yüksekti. $(t=5.661, p<0.001)$

\section{Tartışma ve Sonuç}

Obezite, hiperinsülinizm, insulin direnci meme kanseri gelișimi, meme kanserinde rekürrens ve ölüm ile ilișkilidir ${ }^{15-21}$ Hayvan çalışmalarında tamoksifenin direct beta hücre apopitozunu arttırdığı ve insülin sekresyonunu azalttığ 1 gösterilmiştir ${ }^{14}$. Çalışmamızda tamoksifen tedavisi altındaki 30 kişinin 15 'inde yeni tanı diyabet gelişmiştir. Tamoksifenin yan etkileri içinde yer alan hipertrigliseridemi ve steato-hepatit de insülin direnci ve glukoz intoleransı ile ilişskilidir ${ }^{22 .}$

Çalışma grubumuzda tamoksifen kullanan ve kullanmayan hastalarda ultrasonografik olarak steatoz varlığı ve diyabet gelişimi ile ilgili istatistiksel anlamlı ilişki saptanmadi. Bunun yanında bazı yayınlarda tamoksifen tedavisinin östrojen reseptörü pozitif hastalara başlanması ve bu hastaların östrojen reseptörü negatif olanlara göre östrojen maruziyetinin ve dolayısıyla diyabete yatkınlığının daha fazla olmasının diyabet gelişiminde rol oynadığı savunulmuştur. Bu ilişkinin zayıf olduğu ve çalışmaların tutarsız olduğunu savunanlar da mevcuttur ${ }^{23,24}$ Çalışmamızda tamoksifen kullanan ve kullanmayan hastalarda yeni diyabet gelişimi açısından istatistiksel anlamlı fark gözlenmedi. Ancak plazma glukoz değerleri açısından değerlendirildiğinde hastaların son kontrollerindeki ölçümlerin tamoksifen kullananlarda kullanmayanlara göre daha yüksek çıktığı ve bunun istatistiksel anlamlı olduğu bulunmuştur. $\mathrm{Bu}$ çalışmayla sonucun tamoksifenin insulin direnci ilişkisiyle açıklamak güçtür. Retrospektif analizimizde tedavi öncesi ve control insulin değerlerinin olmayışı çalışmamızın kısıtlılığıdır. Sonuç olarak çalışmamız tamoksifenin insülin direnci ve diyabet gelişimi açısından de yan etki gelişimi açısından ön gördürücü olacağı düşüncesindeyiz. etkilerini değerlendirmede prospektif randomize kontrollü geniş ölçekli çalışmalara ihtiyaç duyulduğunu göstermiştir. Tamoksifen tedavisi öncesinde hastaların metabolik profillerinin belirlenmesinin de yan etki gelişimi açısından ön gördürücü olacağı düşüncesindeyiz.

\section{KAYNAKLAR}

1. Larsson, S.C. Mantzoros, C.S. Wolk, A. (2007). Diabetes mellitus and risk of breast cancer: a meta-analysis. Int J Cancer, 121:856-862.

2. Lipscombe, L.L. Goodwin, P.J. Zinman, B. McLaughlin, J.R. Hux, J.E. (2006). Diabetes mellitus and breast cancer: a retrospective population-based cohort study. Breast Cancer Res Treat. 98:349-356.

3. Van den Brandt, P. A. Spiegelman, D. Yaun, S.S. et al. (2000). Pooled analysis of prospective cohort studies on height, weight, and breast cancer risk. Am J Epidemiol. 152: 514-527.

4. Trentham-Dietz, A. Newcomb, P.A. Storer, B.E. et al.(1997). Body size and risk of breast cancer. Am $J$ Epidemiol. 145:1011-1019.

5. Key, T.J. Appleby, P.N. Reeves, G.K. et al.(2003). Body mass index, serum sex hormones, and breast cancer risk in postmenopausal women. $J$ Natl Cancer Inst. 95:1218-1226.

6. Shoelson, S. E. Lee, J. Goldfine, A. B. (2006). Inflammation and insulin 
resistance. J Clin Invest. 116:17931801.

7. McCarthy, N. J. (2004). Care of the breast cancer survivor: increased survival rates present a new set of challenges. Postgrad Med. 116:39-40, 42, 45-46.

8. Goldhirsch, A. Glick, J.H. Gelber, R.D. Coates, A.S. Thurlimann, B. Senn, H.J. (2005). Meeting highlights: international expert consensus on the primary therapy of early breast cancer 2005. Ann Oncol. 16:1569-1583.

9. Liu, S. Mauvais-Jarvis, F. (2009). Rapid, nongenomic estrogen actions protect pancreatic islet survival. Islets. 1:273-275.

10. Liu, S. Mauvais-Jarvis, F. (2010). Minireview: Estrogenic protection of beta-cell failure in metabolic diseases. Endocrinology. 151:859-864.

11. Louet, J.F. LeMay, C. Mauvais-Jarvis, F. (2004). Antidiabetic actions of estrogen: insight from human and genetic mouse models. Curr Atheroscler Rep. 6:180-185.

12. Barros, R.P. Machado, U.F. Gustafsson, J.A. (2006). Estrogen receptors: new players in diabetes mellitus.Trends Mol Med. 12:425-431.

13. Godsland, I. F. (2005). Oestrogens and insulin secretion. Diabetologia. 48:2213-2220

14. Le May, C. Chu, K. Hu, M. et al. (2006). Estrogens protect pancreatic beta-cells from apoptosis and prevent insulin-deficient diabetes mellitus in mice. Proc Natl Acad Sci USA. 103:9232-9237.

15. Majed, B. Moreau, T. Asselain, B. (2009). Overweight, obesity and breast cancer prognosis: Optimal body size indicator cut-points. Breast Cancer Res Treat. 115:193-203.

16. Enger, S.M. Greif, J.M. Polikoff, J. et al. (2004). Body weight correlates with mortality in early-stagebreast cancer. Arch Surg. 139:954-958.

17. Petrelli, J.M. Calle, E.E. Rodriguez, C. et al. (2002). Body mass index, height, and postmenopausal breast cancer mortality in a prospective cohort of US women. Cancer Causes Control. 13:325-332.

18. Borugian, M.J. Sheps, S.B. Kim-Sing, C. et al. (2003). Waist-to-hip ratio and breast cancer mortality. Am J Epidemiol. 158:963-968.

19. Caan, B.J. Kwan, M.L. Hartzell, G. et al. Pre-diagnosis body mass index, post-diagnosis weight change, and prognosis among women with early stage breast cancer. Cancer Causes Control. 19:1319-1328.

20. Abrahamson, P.E. Gammon, M.D. Lund, M.J. et al. (2006). General and abdominal obesity and survival among young women with breast cancer. Cancer Epidemiol Biomarkers Prev. 15:1871-1877.

21. Hebert, J.R. Augustine, A. Barone, J. et al. (1988). Weight, height and body mass index in the prognosis of breast cancer: Early results of a prospective study. Int J Cancer. 42:315-318.

22. Elisaf, M.S. Nakou, K. Liamis, G. Pavlidis, N.A. (2000). Tamoxifen induced severe hypertriglyceridemia and pancreatitis. Ann Oncol. 11:10671069.

23. Yang, X.R. Chang-Claude, J. Goode, E.L. et al. (2011). Associations of breast cancer risk factors with tumor subtypes: a pooled analysis from the Breast Cancer Association Consortium studies. J Natl Cancer Inst. 103:250263.

24. Suzuki, R. Orsini, N. Saji, S. Key, T.J. Wolk, A. (2009). Body weightand incidence of breast cancer defined by estrogen and progesteronereceptor status-a meta-analysis. Int J Cancer, 124:698-712. 